\title{
Domestic Waste Mass Estimation and Perceptions of Coastal Citizen about Waste Management in Besuki Region, Situbondo, East Java, Indonesia
}

\author{
Wazirotus Sakinah ${ }^{1, *}$, Dina T Septiningtyas ${ }^{1}$, and Anita D Pahlewi ${ }^{1}$ \\ ${ }^{1}$ Universitas Abdurachman Saleh, Situbondo, 68312, Indonesia
}

\begin{abstract}
Coastal citizen in Besuki region have a habit of throwing garbage directly into estuary and sea. To know the bad conditions that can occur in the marine environment especially in Besuki region so domestic waste mass estimation is needed. Proportional random sampling is used to determine the number of samples and measurement of domestic waste is conducted for 8 days. Measurement with SNI (Indonesia National Standard) Number 19-3964-1994 method is used. To know perceptions of coastal citizen about waste management, the distribution of questionnaires to the sample was done. The result is waste mass estimation in Besuki Coastal Region is $167.57 \mathrm{~g} /$ people.day where non-organic waste more than organic waste that has percentage $63 \%$ and $37 \%$, respectively. From questionnaire survey, $73 \%$ citizen throw their wastes in the sea or/and the river, $27 \%$ has been burned, and $0 \%$ in landfill. Generally, $80 \%$ citizens do not have the basic knowledge about marine debris impact and $20 \%$ citizens have knowledge about marine debris impact. Their interest about selfwaste management is $33 \%$.
\end{abstract}

\section{Introduction}

Indonesia as the second largest contributor of plastic waste in the world is the main topic of the conversation of the world community today. Every year Indonesia donates about 3.2 million tons of plastic waste [1]. On March 2018, plastic waste in Jakarta bay became a big issue in Indonesian news. The thickness of waste in Jakarta bay about 1 meter above the sea surface level. The Indonesian Biodiversity Foundation (Kehati) predicts that the plastic waste that is constantly polluting the Jakarta bay area will be a ticking time bomb if not handled quickly [2]. Adding the facts that waste pollution become an urgent problem in Indonesia. Waste pollution cannot separate from plastic waste. Plastic waste is generally discarded in waters from the river that will eventually empty into the ocean and directly discharged into the sea. Similarly, the coastal citizens in Besuki region generally have a habit of throwing garbage directly into estuary and

* Corresponding author: wazirotus.sakinah@gmail.com 
sea. Once introduced into rivers, plastic debris may sink, be deposited on river banks and/or undergo transfer to the marine environment [3]. Plastic debris cannot decomposed easily. In a long time, it transform to microplastic, it is not dissapear from the environment. It can bring negative impacts on many aspects, not only endanger the livelihood of people but it also threatens to poison marine ecosystems.

Marine ecosystems in Indonesia have been much damaged. Mangrove area in Indonesia until 2010 from Ministry of Environment Indonesia has percentage $56.91 \%$ in good condition, $10.69 \%$ medium, $7.20 \%$ damaged, and $25.20 \%$ unidentified. As for coral reef data from the results of oceanographic research LIPI in 2012 showed only $5.30 \%$ in very good conditions, $27.19 \%$ good, $37.25 \%$ good enough, and $30.45 \%$ less good [4]. A previous study between 2011 and 2014 found reefs near Indonesia were littered with the most plastic, while the lowest concentration was found in Australia [5]. Similarly, the seagrass condition also has been much damaged. Seagrass beds are vulnerable to natural disturbance and human activities, including the agricultural waste disposal, oil spill, and organic waste [6]. The impact of waste pollution also bring the effect on animal welfare. As example crocodile with tyre choker found in Palu, Central Sulawesi. Another case happened in Makassar, anthropogenic debris was found in $28 \%$ of individual fish and in 55\% of all species. All of the anthropogenic debris recovered from fish in Indonesia was plastic [7].

Previous research examined composition of municipal solid waste (MSW) during the period of 2000 - 2006 in Taiwan. There are increasing amount of MSW in Taiwan from year to year [8]. Due to this phenomenon proper waste management is needed as a public benefit and obligation. Improper waste disposal by one individual affects the entire citizen [9]. But, as in many regions in Indonesia, waste management is a complex issue. Generally, citizen have a poor waste management, throw their wastes in the waters is the most treatment that always happen in Besuki coastal region. The highlights of this current study to investigate how much waste that produces per day in this region and perceptions of citizen about waste management in their place.

The paper is organized as follows. It begins by preliminary survey for marine debris in Besuki coast, listing the methods used to examine debris mass and types, and citizen perceptions about debris disposal practices and the factors.

\section{Study Area}

The study area is located in Pesisir village, Besuki region, Situbondo, East Java, Indonesia. Geographically located in 7.725 South latitude and 113.686 East longitude. 


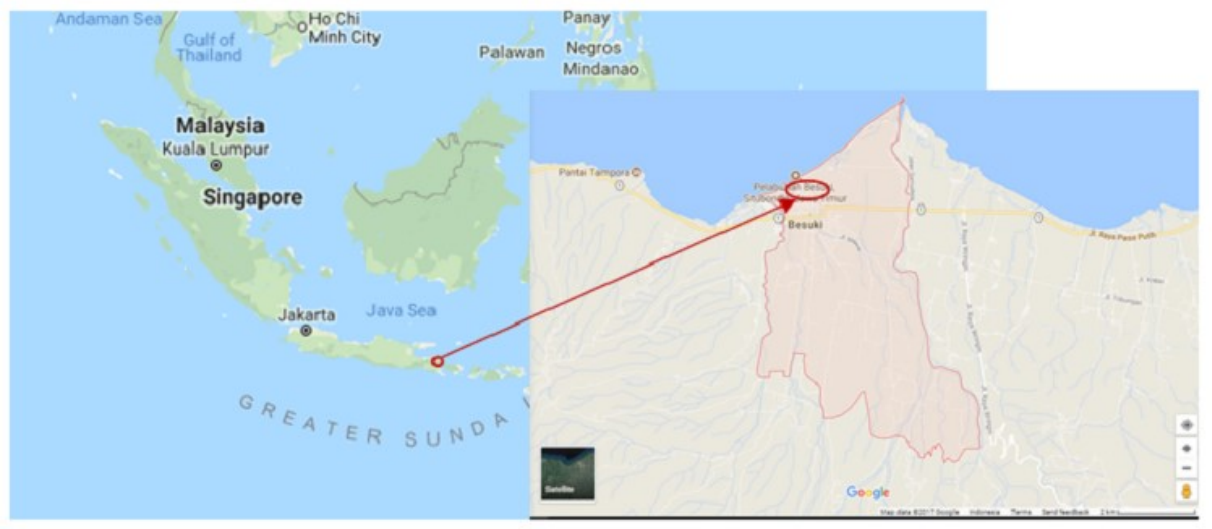

Fig. 1. Study area

\section{Material and Method}

This research did two kinds of method, field measurement with proportional sampling method and giving questioner to some citizen as sample. Field measurement was done at October 2017. Sample determination based on proporsional random sampling, ie the samples were taken randomly on each unit of the settlement area with the number of different samples in each unit of the settlement. Sampling was did in 8 (eight) days respectively at the same location with sampling time 24 hours for each sample [10]. Digital scale is used to measure domestic waste mass. The formula to measure the estimation of domestic waste mass is:

$=\frac{\left(\frac{B_{S 1}}{u}+\frac{B_{S 2}}{u}+\cdots+\frac{B_{S n}}{u}\right)}{S n} \mathrm{~g} /$ people/day

where:

$\mathrm{B}_{\mathrm{s}} \quad=$ measure of waste mass (g/day)

$\mathrm{u} \quad=$ unit of waste producer (people)

$\mathrm{Sn} \quad=$ number of sample (people) [3]

Questionnaires are used to obtain perceptions of coastal citizens about waste management. The questionnaire contains several questions covering how citizen do waste management, are they do the sorting of waste, their knowledge of marine debris impact, and their interest in self-management waste.

\section{Result and Discussion}

\subsection{Domestic Waste Mass in Besuki Coastal Region}

Generally, up to $80 \%$ marine debris comes from land-based sources, which is transported via sewage/drainage system, natural waterways, wind or human neglect [11, 12]. Mostly, the disposal is plastic including plastic garbage bags and other plastic products. This statement can be proven from our preliminary survey in Figure 2. 


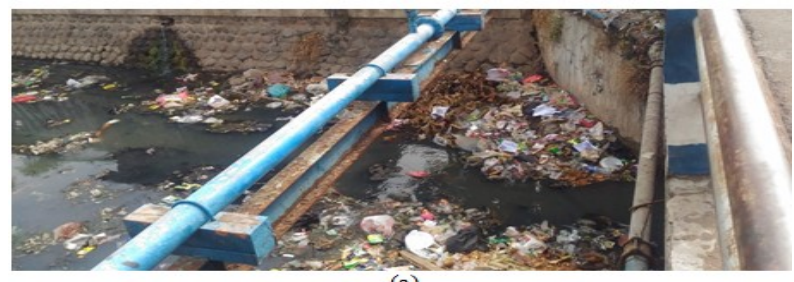

(a)

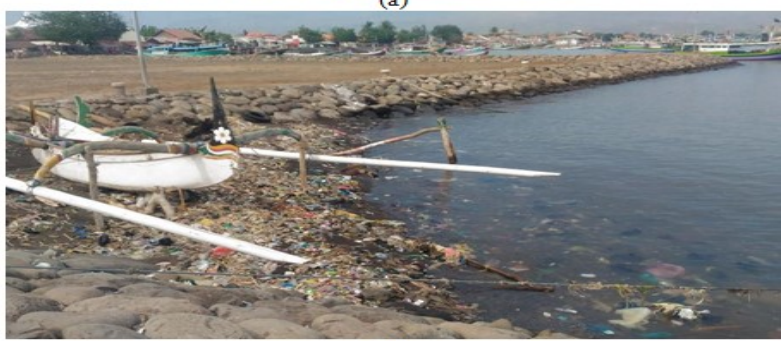

(b)

Fig. 2. Preliminary condition in Besuki region, (a) garbage in river, (b) garbage in coastal area

Plastic, the most marine debris in Besuki region, was known from Figure 2, is the difficult waste to decompose. For example plastic bottles, bottled water is carried on board for drinking and/or cooking purposes and plastic bags that are commonly used to pack goods or other types of waste [12].

Based on data from the statistical center agency, population in Besuki is 64,655 people with coastal region has 10,021 citizen, where the average household size was 5 people. The results based on sampling data collection methods can be seen in Table 1 .

Table 1. Domestic waste mass from sampling data collection in Besuki coastal region.

\begin{tabular}{|c|l|c|r|r|}
\hline Sampling & \multicolumn{2}{|c|}{ Total mass } & \multicolumn{1}{c|}{ Total (g) } & \multicolumn{1}{c|}{ Total (g) } \\
\hline \multirow{2}{*}{ day- } & \multicolumn{2}{|c|}{ (g/household.day) } & waste/day & waste/unit/day \\
\cline { 2 - 5 } & Organic & non organic & & \\
\hline 1 & 221,7 & 1224,0 & 1445,7 & 289,14 \\
\hline 2 & 469,9 & 649,0 & 1118,9 & 223,78 \\
\hline 3 & 247,8 & 882,5 & 1130,3 & 226,06 \\
\hline 4 & 589 & 744,9 & 1333,9 & 266,78 \\
\hline 5 & 565,1 & 660,7 & 1225,8 & 245,16 \\
\hline 6 & 219,4 & 295,5 & 514,9 & 102,98 \\
\hline 7 & 507,2 & 358,3 & 865,5 & 173,1 \\
\hline 8 & 298,7 & 444,8 & 743,52 & 148,704 \\
\hline Average & \multicolumn{3}{|}{} & 1047,315 \\
\hline Total & \multicolumn{4}{|l}{} \\
\hline Estimate g/people.day & & & 1675,704 \\
\hline
\end{tabular}


Throughout sampling data collection, the domestic waste mass in Besuki region are always changing. The waste mass in each household is $1,047.32 \mathrm{~g} /$ day so the estimation waste mass in Besuki coastal region is $167.57 \mathrm{~g} /$ people.day. If this amount is multiplied by the number of inhabitans in Besuki coastal region, then the amount will be obtained $1679 \mathrm{~kg}$ /day or 1,68 tons of garbage every day in that region. The fact is, most of the waste end as marine debris as on Figure 2. Such as previous research, most of municipal solid waste still dumped or landfilled, especially in countries with low income per capita and globally just about $15 \%$ is recycled [13]. Generally, domestic waste from Besuki coastal region has non-organic waste more than organic waste, it can be seen on Figure 3.

Organic waste and non-organic waste from sampling data collection has percentage $73 \%$ non-organic waste including papers and plastics which have percentage $33 \%$ and $40 \%$, respectively and $27 \%$ organic waste such as food garbage from total waste sample in 8 days. Decompose of organic waste such as fermentation for food waste need 4 days with act in anaerobic bacteria [14]. But, decompose non-organic waste need longer time. Plastic bags, the common item in Besuki coastal region domestic waste, take 101000 years to decompose. Another common item is paper waste, it takes 2-6 weeks to get completely decomposed and fruit peel takes months to decompose [15]. The long time it takes waste to decompose causes the build-up of waste, especially in the river and sea in Besuki coastal region.

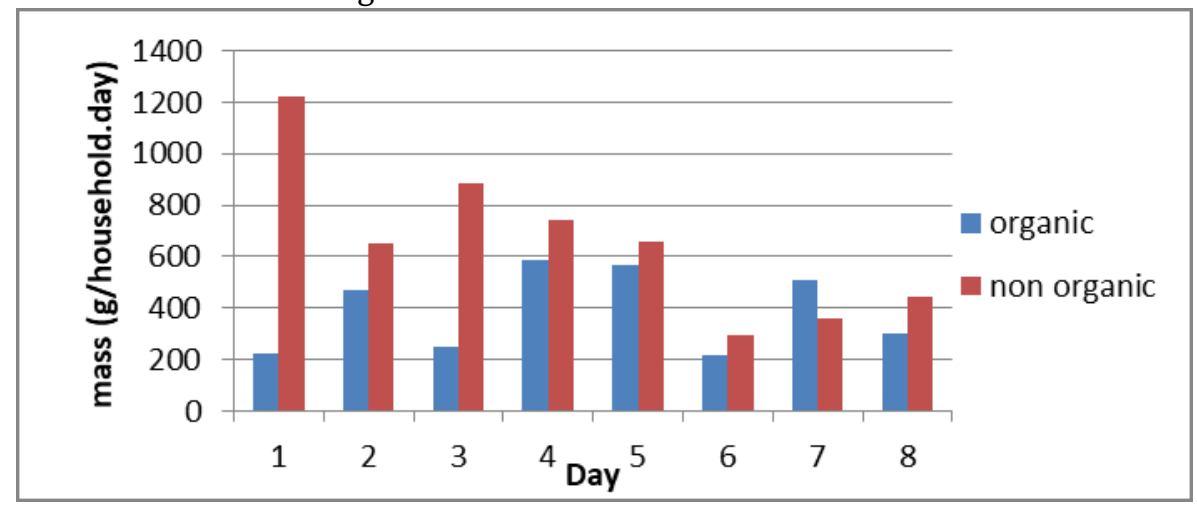

Fig. 3. Comparison of organic and non-organic waste in Besuki coastal region

\subsection{Perceptions of Besuki Coastal Citizen about Waste Management}

A total 4 questions for each sampled households respondents was used for the survey questionnaire. The questionnaire is multiple choice questions because some respondents are illiterate. The first question about waste management. $73 \%$ respondents throw their waste in the sea or river and $27 \%$ waste are burned, see Figure 4. 


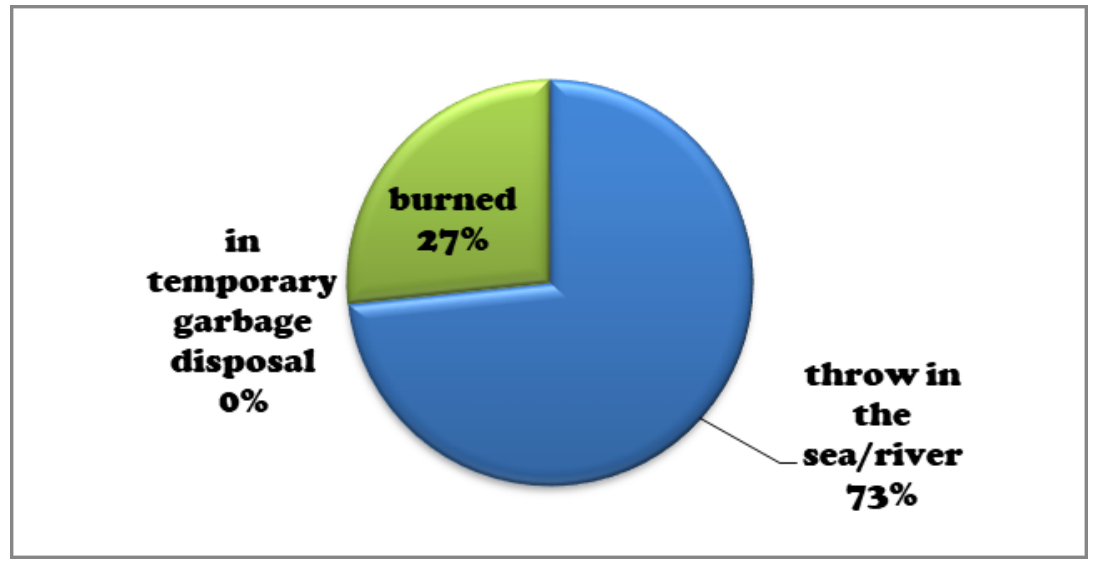

Fig. 4. Waste management diagram in Besuki coastal region.

Generally, the reason why they usually throw their waste to the waters is waste can flow straight away. The reason why wastes are burned is another people throw the waste near the sample house. There are no one throw their waste in landfill because there is no landfill in this region. This waste management can be considered as a traditional common. A traditional commons that seeing the ocean as a dumping ground for waste make a tragedy in the global oceans. Absenting a governance system to impose rules for behaviour and the rational individual sees that the shared cost of polluting are often smaller than personally paying for the processing of their waste [16]

The second question about sorting waste. $87 \%$ respondents said they do not sort their waste because there is no place and they do not know why sorting waste is needed. $13 \%$ respondent sort their waste because some waste can be sold. Generally, they do not know about marine debris impact. From all respondent, only $20 \%$ know about the impact of marine debris. It is make them to have a bad habit to throw their waste to the waters. Finally, they do not interest about self waste management. It can be seen from the questionnaire result, only $33 \%$ said they interest about self waste management. Lower middle countries has percentage $49 \%$ waste is dumped, $11 \%$ landfilled, $2 \%$ composted, and just $5 \%$ is recycled [13].

Table 2. The result of questionnaire

\begin{tabular}{|l|l|c|}
\hline No & \multicolumn{1}{|c|}{ Descriptions } & Percentage \\
\hline 1. & Waste Management & \\
& - Throw in the sea/river & $73 \%$ \\
& - Burned & $23 \%$ \\
& - Landfill & $0 \%$ \\
\hline 2. & Sorting waste & \\
& - Yes & $13 \%$ \\
& - No & $87 \%$ \\
\hline 3. & Knowledge on marine debris impact & $20 \%$ \\
& $-\quad$ Yes & $80 \%$ \\
\hline 4. & Self waste management interest & \\
& $-\quad$ Interest & $33 \%$ \\
& $-\quad$ No interest & $67 \%$ \\
\hline
\end{tabular}

The third question about their knowledge on marine debris impact. $80 \%$ respondents does not know about marine debris impact. It makes them pay less attention to their 
environment. It is the reason why Besuki region has a poor waste management today. The last question about the respondents interest on self waste management. $67 \%$ respondents does not have interest on self waste management. Generally, they does not know why they need to manage their waste. This question have correlation to the third question. Poor knowledge about marine debris impact make a poor waste management. Finally, they are not interested in managing their waste independently.

\section{Summary}

The waste in Besuki coastal region was dominated by non-organic type which mass in each household is $1,047.32 \mathrm{~g} /$ day, while the estimation waste mass in its region is $167.57 \mathrm{~g} /$ people.day. $73 \%$ of people throw their wastes in the sea or/and the river, $27 \%$ of wastes was burned, and $0 \%$ of people throw their wastes in landfill, it means that they have a bad habit of disposal debris. Generally $80 \%$ of them do not have the basic knowledge about marine debris impact. While, based on the survey, $33 \%$ of them has a good interest about self-waste management. So, from the data above we can conclude that Besuki Coastal Region has a poor waste management.

\section{References}

1. Information on http:// www.cnnindonesia.com

2. D. Prasongko, Plastic pollution; ticking time bomb in Jakarta Bay (Tempo.co, 2018)

3. J. Gasperi, R. Dris, T. Bonin, V. Rocher, B. Tassin, Env. Pollut. 195, 163 (2014)

4. B. Pramudyanto, Jur. Ling. Wid. 1:4, 21 (2014)

5. M. Ompusunggu, Study to challenge claim Indonesia second-biggest marine polluter (The Jakarta Post, 2018)

6. Greenpeace Southeast Asia, Greenpeace laut Indonesia dalam krisis (Greenpeace Southeast Asia, Jakarta)

7. C. M. Rochman, A. Tahir, S. L. Wiliams, D. V. Baxa, R. Lam, J. T. Miller, FC. Teh, S. Werorilangi, S. J. Teh, Anthropogenic debris in seafood: Plastic debris and fibers from textiles in fish and bivalves sold for human consumption (Scientific Reports, 2015)

8. W. T. Tsai, Bior. Tech. 99, 5309 (2008)

9. R. M. Yoada, D. Chirawurah, P. B. Adongo, BMC. Pub. H. 14:697, 1 (2014)

10. SNI 19-3964-1994, Metode Pengambilan dan Pengukuran Contoh Timbulan dan Komposisi Sampah Perkotaan BSN

11. D. A. Cooper, P. L. Corcoran, Mar. Pol. Bul. 60, 650 (2010)

12. C. L. Chen, T. K. Liu, Mar. Pol. 40, 34 (2013)

13. H. Jouhara, D. Czajczyńska, H. Ghazal, Krzyżyńska, L.Anguilano, Energy 139, 485 (2017)

14. R. Slezak, J. Grzelak, L. Krzystek, S. Ledakowicz, Was. Man., (Article in Press) (2017)

15. W. Rathje, C. Murphy, Rubbish! The Archaeology of Garbage (The University of Arizona Press, Tucson, 2001)

16. L. L. Micah, Mar. Pol. Bul. 127, 310 (2018) 